\title{
Botanic gardens and plant pathogens: a risk-based approach at the Royal Botanic Garden Edinburgh
}

\section{Katherine Hayden ${ }^{1}$}

\begin{abstract}
Introduced and emerging plant diseases as a result of live plant movements are increasingly recognised as a global environmental and economic threat. This presents a fundamental challenge to botanic gardens and other ex situ plant conservation organisations: how to continue this important work while recognising and mitigating the plant health risks. The approach taken by the Royal Botanic Garden Edinburgh is presented as a case study, showing how we have reduced ecological and evolutionary opportunities for pests in ex situ conservation and are monitoring the success of these efforts. We have developed protocols in quarantine and horticultural practice, expanded visitor engagement and public education, and taken a precautionary approach towards plant distribution supported by in-house diagnostics and working closely with statutory authorities. We hope that by sharing activities as well as difficulties, botanic gardens can acknowledge and address the new biosecurity landscape.
\end{abstract}

\section{Introduction}

Plants are globally threatened (Corlett, 2016; Pimm \& Raven, 2017) and botanic gardens play a key role in delivering plant conservation through the Convention on Biological Diversity (CBD). This is essential plant conservation work, though it also represents a risk consistent with the increasing prevalence of emergent plant disease, driven largely by global trade (Brasier, 2008; Desprez-Loustau et al., 2009; Roy et al., 2014). The movement of plant material into ex situ collections is both a benefit for conservation and a potential problem if pests (defined here broadly as all organisms harmful to plants such as nematodes, insects and microbial pathogens) are also transported with plants into new environments where they are outside the checks and balances of the ecosystems within which they have co-evolved (Gilbert, 2002; Desprez-Loustau et al., 2007, 2015; Ennos, 2015). Indeed, disease associated with pest introductions are an increasing threat to biodiversity worldwide, and across taxa (Fisher et al., 2012; Bebber et al., 2014). Because live plant movement is one of the greatest risk factors for pest introduction (Liebhold et al., 2012; Santini et al., 2013; Sikes et al., 2018), the very act of ex situ conservation carries with it the risk of creating new conservation problems.

The collective weight of botanic gardens - administered through Botanic Gardens Conservation International (BGCl) - has developed and is delivering the Global Strategy for Plant Conservation (GSPC), a platform focusing on plant biodiversity within the CBD. The GSPC has five objectives delivered by sixteen targets; they include, for

${ }^{1}$ Katherine Hayden is Mycologist and Plant Health Officer at the Royal Botanic Garden Edinburgh. Address: 20A Inverleith Row, Edinburgh, EH3 5LR, UK. 
example, "At least $75 \%$ of threatened plant species in ex situ collections, preferably in the country of origin, and at least $20 \%$ available for recovery and restoration programmes" (Target 8). The GSPC utilises the strengths of botanic gardens in sampling, growing, protecting and studying, and then restoring to the wild, plant species and their genetic resources. Botanic gardens are therefore involved in the transport of plant resources from around the globe, both nationally and internationally, to a single location, with redistribution for conservation purposes.

It is estimated that 30 per cent of all known plant species are under cultivation in botanic gardens, including 41 per cent of threatened species (Mounce et al., 2017); these will often include a mixture of plants of international as well as national origin. As an example, the Royal Botanic Garden Edinburgh (RBGE) currently holds approximately 130,000 plants in its Living Collection, comprising 13,750 species originating from 163 countries. Of these, 61 per cent are of wild origin (RBGE, 2018). In terms of national collections, c. 85 per cent of threatened Scottish plants are cultivated as ex situ collections at RBGE, for their remedial protection and subsequent use in habitat restoration programmes. As a resilience mechanism, the resources in botanic gardens are shared with sister organisations and arboreta both nationally and internationally.

In order to ensure operational continuity of their essential conservation work, and in light of the known risks associated with live plant movements, botanic gardens must increase the scale of their investment in plant biosecurity in at least three ways:

1. Investing in staff who have the knowledge to manage the complex and fast-changing environment of plant biosecurity, through training or recruitment.
2. Investing in robust screening and monitoring systems to create new knowledge that - through periodic review - informs best practice.

3. Using their authoritative voice to provide training and information on biosecurity to the wider community involved in plant collecting, ecological restoration and horticulture, and, as visitor attractions, to the general public.

With the aim of achieving effective plant conservation while minimising risks from pests, RBGE has made investments in each of these areas. In this paper, we discuss these efforts as well as ongoing challenges.

\section{Background}

Botanic gardens are currently regulated by national and international legislation. Most broad-reaching is the International Plant Protection Convention (IPPC, 1997), first enacted in 1951, which has as its goal the prevention of international movement of pests harmful to cultivated plants and provides a framework for the establishment and cooperation of national and regional regulatory authorities for plant import and export. These national and regional authorities then provide additional requirements and guidance. Within Europe, European Directive 2000/29/EC specified harmful pests which if found in a European country precipitated measures for eradication or control. This has been superseded by the Regulation (EU) 2016/2031 which shifts focus away from reaction to specified threats towards a proactive protection of natural assets. For example, it will enact a near-complete ban on importing plants and cuttings of some genera, scheduled to begin in December 2019, on the rationale that these may bring unknown threats to their 
European congeners (European Parliament and Council of the European Union, 2016). Plant health law is most frequently oriented towards commercially important plants, however, and the application of phytosanitary restrictions towards non-commercial species varies widely (Eschen et al., 2015). Requirements may include import restrictions on particular species or genera with economically important relatives (for example, importing plants or seed of Solanum $\mathrm{sp}$. is highly restricted in Scotland because of the significance of the potato as a commercial crop in this country), or removal of soil and visual inspection of plants before arrival and during a quarantine period. In most cases, plant inspections and quarantine release rely on visual inspection: if a plant shows signs or symptoms of any disease during the quarantine period it cannot be released until it has been judged by a plant health officer to be free of pests.

Notwithstanding the visual inspection for disease during the quarantine procedure, plants have diverse microbial epiphytes and endophytes, and it is nearly impossible to move plants without also moving these microbial associates. Soil and growing media are invariably a rich medium for microbes and latent pests, but washing them free of organic matter does not remove this community of associated microbes. While in vitro propagation can help to establish plants without pests, it has long been documented that fungi, bacteria, viruses and even small arthropods can sometimes persist through these efforts (Leifert \& Cassells, 2001). Moreover, it may be undesirable to reduce the microbiome of a plant, since it appears to play a regulatory role in plant health, including through disease resistance (Arnold, 2003; Adame-Álvarez et al., 2014; Busby et al., 2015, 2016). There is a fundamental contradiction and unresolved paradox in this: microbial associates can be critical for plants' successful establishment, and yet introduction of unknown plant-associated microbes to a new system is ultimately a major plant health risk.

The two key questions in managing the supply, protection and translocation of plants as they are processed through a botanic garden are as follows:

1. What can be done to reduce the ecological and evolutionary opportunities for pests in ex situ conservation?

2. How can the effectiveness of these procedures be monitored?

Faced with the complexity of the plant microbiome, RBGE's answers to these questions have focused on known risks such as Phytophthora oomycetes. Taxa that have emerged as problem species and are spreading in the UK, such as P. pseudosyringae and $P$. ramorum, are used as indicators for any potential weakness in horticultural procedure. This approach has been validated by other nursery sanitation programmes, such as the systems approach for nursery biosecurity advocated by Parke \& Grünwald (2012) and the screening programmes for native plant nurseries in California (Rooney-Latham et al., 2018; Sims et al., 2019) (see Frankel et al. in this issue) and elsewhere (see Summerell \& Liew and Green et al. in this issue).

Question 1: what can be done to reduce the ecological and evolutionary opportunities for pests in ex situ conservation?

Micro-organisms that have co-evolved with plants occur along a continuum from commensals to pathogens, and their position along this continuum can depend 
on environmental context (Stergiopoulos \& Gordon, 2014) (see Antonovics \& Hayden, this issue). This poses a problem in the visual inspection for disease-carrying plants during quarantine (see above), and is a particular problem in a botanic garden setting for ecological and evolutionary reasons.

The number of opportunities for invasion are important in determining the eventual success (defined here as establishing a reproducing population) or failure of an invasive non-native species (INNS). To invade a new locale successfully, a pest will follow the INNS model in needing to meet a threshold of new infections and transmissions to keep from dying out. The more chances there are for a pest to colonise and/or establish (that is, the greater the number of introductions), the greater the likelihood of a successful invasion. This can be a function either of numbers, i.e. there being sufficient number to overcome inevitable losses during establishment in a harsh environment, or of the arrival of new genotypes allowing for adaptation (Simberloff, 2009).

The primary course of action is thus to minimise opportunities for pest establishment, firstly in the imported plant or seedling, and secondly on its neighbours.

At RBGE, we have attempted to meet this challenge through the following activities:

- quarantine and horticultural awareness and reporting of plant health issues effected by good collaboration between science and horticulture divisions

- visitor engagement and public behaviour change

- a precautionary attitude including running our own molecular diagnostics programme, and close liaison with statutory authorities.
Minimising sources of contamination and transmission in the RBGE Living Collection starts with quarantine at entry. The statutory specification for "a full growing season" is interpreted to be a minimum of 12 months in quarantine for plants from overseas origins, and that rigour is extended to all plants from outside the UK, including Europe, and for any high-risk origins within the UK, such as international plant collections received from other botanic gardens and arboreta. Plants that arrive in the collection from lower-risk origins in the UK are also inspected on entry and secluded for a period of time within the nursery area, then re-inspected before entering the collection.

In practice, this means that for plant movement to RBGE from low-risk sources, such as native habitats within the UK, plants would enter a non-quarantined seclusion zone within the RBGE nursery facility or a similar designated facility at its satellite gardens, while plants from outside the UK (or of high-risk origin with the UK) are placed into a closed quarantine facility for a full growing season, i.e. for a minimum period of 12 months.

Procedures within the propagation nursery have also been reviewed and revised to minimise sources of pest contamination and transmission. Mains water is used for irrigation, with no recycling of irrigation water. Plants have been lifted off the ground, shifting the dominant mode of plant storage from directly on Mypex sheeting over gravel, to benches well off the surface. Access to the indoor propagation houses is controlled, shoes and hands are cleaned on entry and workflows have been rearranged in order to travel from 'clean' to 'dirty' in order to minimise contamination sources. Pots are sanitised with hot water or chemicals between use, and dirty pots are stored well 


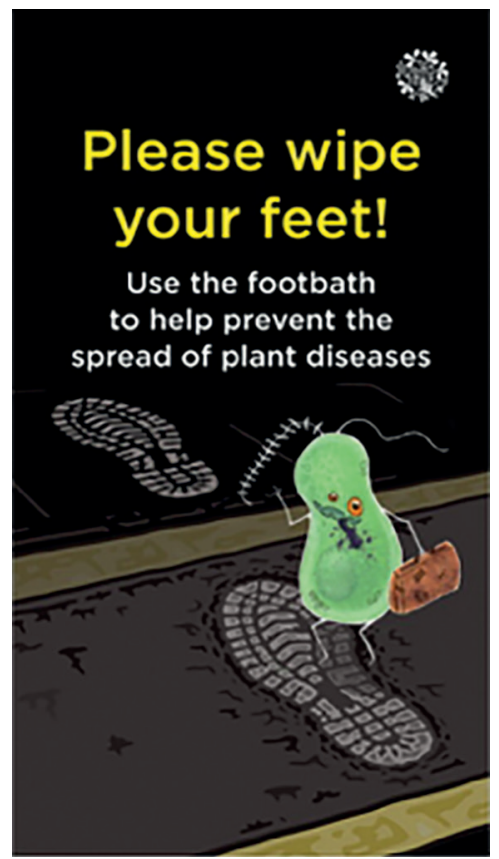

Fig. 1 Signs placed alongside footbaths explain and encourage their use. Sign: Vlasta Jamnický.

away from potting media or clean pots and surfaces (Sims et al. 2019; Suslow, 2007).

Within the Living Collection, staff-led initiatives have created mobile biosecurity kits, particularly for use by the arboriculture team when treating and removing diseased trees, foot dips for staff at the research glasshouses, and staff notice boards providing explanation and guidance. Quarantine staff keep dedicated tools within the quarantine glasshouse, with designated areas and lab coats for intake inspection. Separate lab coats are used in the remaining areas of the quarantine glasshouses. Plant health checks are undertaken regularly in quarantine, and outbreaks of any kind of pest, whether widespread or a suspected introduction, are recorded along with the management response. Plants released from quarantine after a full year or a full growing cycle, whichever comes later, must be free of signs and symptoms of pests.

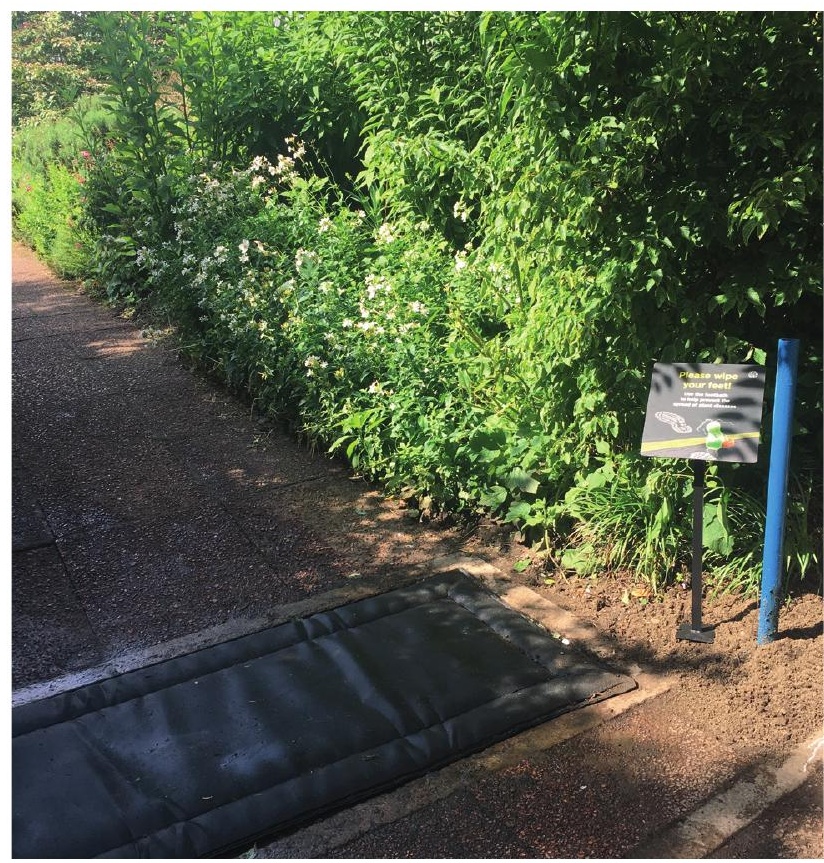

Fig. 2 Footmats disinfect the soles of shoes. Photo: Vlasta Jamnický.

While visitor behaviour is more unpredictable, we have extended biosecurity messages to the public through interpretation and engagement. Disinfectant footbaths were introduced in 2009 in response to the Phytophthora ramorum outbreak in Scotland, and made permanent when it became clear there would be no reduction in the threat of introduced plant pests to the living collections. Thus, every visitor to the Garden enters by passing through a disinfectant footbath, physically interacting with biosecurity measures (Figs 1 \& 2). These are accompanied by signs with a short visual message to use the footbaths to help prevent plant disease. In the John Hope Gateway visitor centre, there is the opportunity to further interact with a permanent exhibit demonstrating the ways that pests can move around the world, and what can be done to help stop this. Cleaning feet and tyres, buying plants from trusted 
local suppliers, and not moving plant and animal products internationally in luggage are all targeted messages.

The second course of action is to reduce opportunity for pest population evolution and survival in a new environment, especially the development of greater aggressiveness by more efficiently exploiting its host resource and/or increasing the chance of jumping to a new host.

This line of action is arguably more complex than the first, although the high host diversity found in botanic garden settings can provide an advantage (Antonovics \& Hayden, this issue). Close horticultural monitoring of plant health and prompt treatment/removal of infected plants can aid in the reduction of pest populations, thereby reducing the chances of spillover to new hosts (Power \& Mitchell, 2004).
A culture of monitoring has been instituted at RBGE's four Gardens, with staff encouraged to report unusual symptoms and sudden deaths. As an example, a conservation hedge comprising 84 individuals of 17 seed families of the endangered conifer Xanthocyparis vietnamensis was removed from the Edinburgh Garden in early 2019, only one year after it was planted (Fig. 3). One individual that died suddenly in January 2019 was observed to have a basal lesion that returned a positive result for a Phytophthora species using an immunoprotein assay (ImmunoStrip $\left.{ }^{\oplus}\right)$. This individual was removed and the remaining trees monitored, but by April of that year an additional 21 individuals had basal lesions and 6 had died. The entire hedge was removed and an experimental treatment of solarisation was begun to reduce the Phytophthora
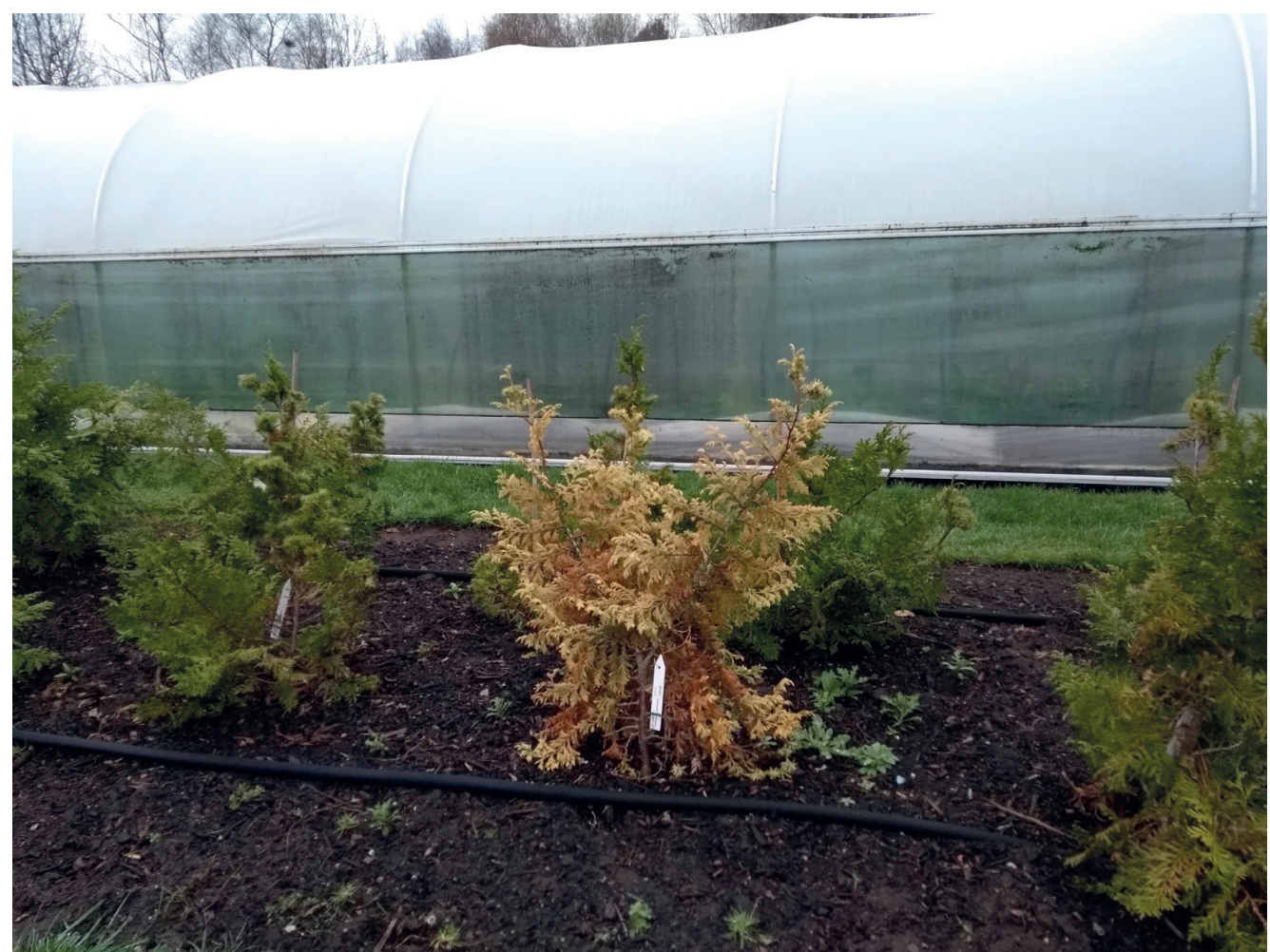

Fig. 3 Xanthocyparis vietnamensis showed signs of disease within a short time of being planted and all the plants were removed when further infection was evident following monitoring. Photo: Katherine Hayden. 
load within the soil bed. In future, curatorial decisions will need to balance the research and educational value of planting individuals of the same species close together, against the advantage such low diversity provides to pest transmission with potential to allow the build-up of large pest populations.

The culture of horticultural monitoring likewise allowed the interception of a quarantine pest in the Edinburgh Garden. Following a finding of Phytophthora ramorum by a staff member in a large rhododendron, the plant and its immediate neighbour were removed in accordance with statutory guidelines (Figs 4 \& 5). The surrounding vegetation was monitored via a government inspection programme and by horticultural staff, and the Phytophthora load in the surrounding area was monitored via baiting of soil samples collected at intervals in crosswise 120-m transects originating from the point of infestation. No new points of infestation have been found as of the time of writing, 16 months after removal, although the possibility of revival or re-infestation from new sources remains.

A similar removal programme was enacted at RBGE's Benmore Botanic Garden, in the west of Scotland, after an outbreak of Phytophthora ramorum in 2010. A study of spore loads (Elliot et al., 2013) demonstrated that a single infested host plant that was allowed to remain in place continued to produce aerial spores and led to additional plant infections nearby, highlighting the difficult choice between preserving individual plants and protecting the rest of the collection. As this first epidemic waned, $P$. ramorum re-emerged elsewhere in Britain as 'sudden larch death' (Brasier \& Webber, 2010), eventually bringing a new epidemic to Benmore's larch trees from 2016 onwards. This epidemic has been more difficult to control.

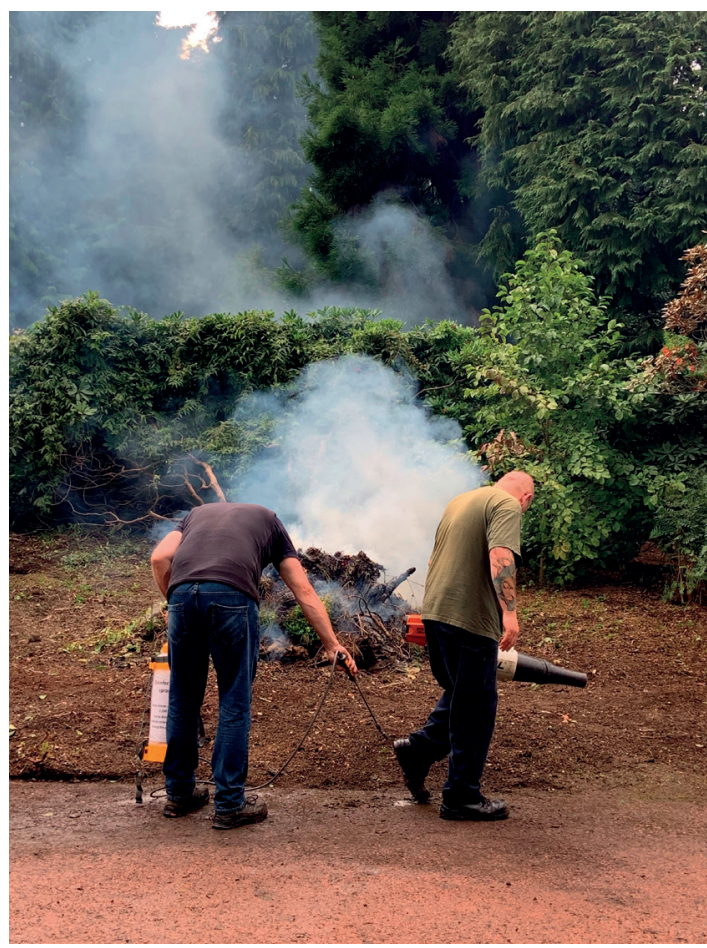

Fig. 4 Two Rhododendron species infected with Phytophthora sp. are burned on site by horticultural staff at RBGE. Shoes and boots are all thoroughly sprayed on leaving the area of infection to reduce transmission of infection. Photo: Kate Hughes.

There is a considerable larch overstorey at Benmore, and a number of larch plantations in the surrounding glen. While larch and other species have been removed at Benmore as infections are spotted, larch may be infected and sporulating for some time before symptoms appear (Harris \& Webber, 2016).

Finally, good horticultural practice can reduce the opportunities for pests. Normal practice to keep plants healthy concurrently reduces pest populations, as stress can increase disease susceptibility.

\section{Question 2: how can the effectiveness of these procedures be monitored?}

Allowing for the invisible nature of plant pests, which may occur in 


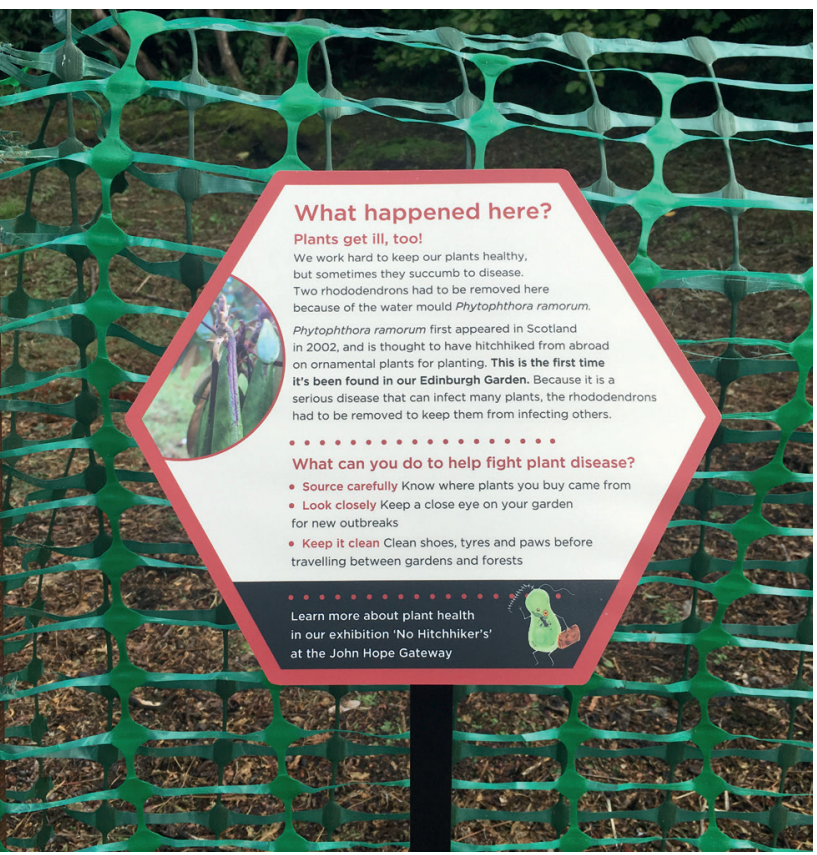

Fig. 5 Signs explain bare planting beds to the visiting public. Photo: Katherine Hayden.

non-symptomatic plants, RBGE has turned to a mixture of traditional methods and molecular diagnostics for proactively detecting them. Given the resource constraint these tools are applied (1) systematically, (2) reactively and (3) using a risk-based approach.

In addition to diagnostics of symptomatic material, RBGE has undertaken a screening system for cryptic soil pests using isolation via baits in the absence of disease symptoms. This has been enacted to screen key risk points in the nursery production system (for example, new batches of purchased compost, water sources) (Parke \& Grünwald, 2012), to test plants destined for translocation programmes, and in some cases to screen plants on entry to the collection. Systematic sampling at randomly placed points has been assayed over time in both the nursery propagation area and in the planted garden to understand the community composition and diversity of Phytophthora species.

Similar screening has been enacted to monitor the effectiveness of interventions, for example, the crosswise transect established to repeatedly sample the zone where Phytophthora ramorum was found and its host removed (see above). These transects serve to monitor the extent of spread of the pathogen (which so far has been localised) and the effectiveness of the removal in decreasing spores in the environment.

Proactive screening is undertaken of plants intended for conservation translocation. Plants are visually inspected prior to translocation, and translocated only if they appear healthy. Additionally, plants are tested for hidden Phytophthora infestations using pear baits of rhizosphere soil or water runoff from planted pots. Baiting is a classic technique in the isolation of oomycetes (Erwin \& Ribeiro, 1996). Briefly, a small amount of plant leachate or rhizosphere soil is collected, and in the case of soil, flooded with water. Unripe, green pears are set in the water, and allowed to incubate for up to seven days. Lesions formed on the bait after incubation are isolated onto selective media, and then identified via morphology and using DNA barcodes.

At RBGE, plants for distribution to gardens, estates, or other areas with a long history of planting are considered to be a moderate risk, given the likelihood of prior introduction of Phytophthora spp. via trade. At least 20 per cent of these plants are screened via baits.

Plants intended for conservation in sensitive sites, for example habitat restoration in wilderness and/or nature 
protection areas, are considered to be at a higher risk, and each plant is baited, in a batch with up to ten other individuals. When species are known to be susceptible to cryptic pests that are not easily detected by baits, they may be examined using targeted PCR (for example, Cupressaceae for Phytophthora austrocedri).

\section{Challenges}

\section{Facilities}

Botanic gardens have finite resources. In particular, the buildings used to house plants during quarantine must balance an expense in building and operation with an ability to limit risk of escape. National statutory guidelines are a minimum standard for containment, and the definition of 'quarantine' may vary among countries or types of plants, from an open field that is regularly inspected to dedicated and highly controlled facilities with management of water runoff and the exclusion of insects and other arthropods (Eschen et al., 2015). Publicly funded gardens may not receive financial support to build facilities beyond statutory requirements, or if they do, they face constraints. For example, climatecontrolled rather than open-vented glasshouses are optimal for biosecurity but incur higher building and operating costs; the associated climate control necessitates a higher carbon footprint. However, when air flow is controlled, outflow can be filtered to remove fungal spores and small arthropods which may otherwise pass through vent screens. Cold lobbies, air showers and negative air pressure systems are likewise recommended to minimise risk of transfer of pests during the quarantine period, but in most cases are beyond statutory requirements and may not be seen to justify public funding.

\section{Balancing disinfectants with} environmental toxicity

Heat- and steam-based sterilisation techniques are effective disinfectants, but are energy intensive and require an investment in equipment and ongoing maintenance and power costs. Chemical disinfectants may be attractive for sanitising equipment and surfaces, but may not be effective against all pests or may be overcome by pest resistance, may be inactivated by organic matter and carry the cost of environmental toxicity (McDonnell \& Russell, 1999; Marchetti et al., 2006; Cheah et al., 2009).

\section{Staff buy-in}

While most horticulturists are professionally dedicated to plant conservation and are happy to adjust or amend practices for good reason, asking staff to change longstanding methods can be interpreted as disrespectful of their expertise. The most successful initiatives to improve biosecurity at RBGE have been (1) supported by proactive curators, (2) led by horticultural staff and (3) accompanied by the resources needed to enact them.

\section{Information management}

Botanic gardens can be excellent at keeping records, but the databases used in many, including at RBGE, have been optimised to record plants rather than any problems associated with them. Expanding current databases to accommodate disease symptoms, diagnoses and pests is a challenge, but also a great research and learning opportunity in generating longitudinal data.

\section{Disincentives for early detection} No curator wants to be the first in their area to record a new pest. First detections carry 
risks of reputational damage - on the faulty assumption that first detection is synonymous with first occurrence - and potential collateral damage to collections from eradication measures. Nonetheless, botanic gardens and arboreta are exceptionally well placed to survey for new outbreaks. To reduce surveillance because of these disincentives would be a missed opportunity: at best, for understanding the true distribution of pests, and at worst, for eradicating an outbreak in its early stages. At RBGE, we are hopeful that frank public interpretation about plant pests will be one step towards reducing stigma (Figs $1 \& 5$ ).

\section{Operational reductions}

Trade-offs are inevitable: a precautionary attitude in quarantine means some plant collections will be destroyed; limiting foot traffic in sensitive areas means public access is reduced; and heightened screening of plants for translocation means that capacity is stretched, while some plants of conservation value must necessarily be discarded to reduce risk to the rest of the collections and the environment.

\section{Conclusions and future directions}

Future questions to be addressed at RBGE include how to move towards entry and exit inspections at a finer scale than visual inspections can provide, even for low-risk situations. This leads to questions on how to reconcile the vast amount of information and inevitable 'unknown taxa' that are discovered with molecular diagnostics, with the concept of a plant microbiome. Can we use molecular diagnostics to distinguish potential latent pests from the members of a healthy microbiome? Similarly, current screening programmes for cryptic pests focus on Phytophthora species as indicator taxa. How can we upscale these to include a wider spectrum of taxa?

Collaboration and knowledge sharing with international partners is key, such as through the International Plant Sentinel Network (see Marfleet \& Sharrock's paper in this issue; Barham et al., 2015). Building platforms on which to pass information will be critical to this end. Finally, knowledge sharing with the public should be expanded. Recent efforts have included training courses for the Botanic Garden Education Network ${ }^{2}$ and participation in Plant Heritage ${ }^{3}$ and Plant Network ${ }^{4}$ workshops, as well as a training course in plant diagnostics in partnership with Scotland's Plant Health Centre ${ }^{5}$ and the British Society for Plant Pathology. ${ }^{6}$

Ultimately, plant conservation organisations face a responsibility to acknowledge and address the new biosecurity landscape. We present RBGE's experience addressing biosecurity challenges for conservation horticulture in order to share learning during a time of rapid change in the spread of pests. International collaboration and further sharing among practitioners will help to address the challenges we present, while flagging still others, and together we may arrive at new solutions.

\section{Acknowledgements}

This work was funded by the Scottish Government funded SEFARI Responsive

\footnotetext{
${ }^{2}$ See https://bgen.org.uk

${ }^{3}$ See www.nccpg.com

${ }^{4}$ See https://plantnetwork.org

${ }^{5}$ See www.planthealthcentre.scot

${ }^{6}$ See www.bspp.org.uk
} 
Opportunity Initiative and as part of the Euphresco International Plant Sentinel Network. The policies and procedures described here were developed with Peter Brownless, David Knott, Fiona Inches, Gunnar $\varnothing v s t e b \varnothing$, Ross Irvine and Louise Galloway. Thanks go to Chris Ellis and Pete Hollingsworth for helpful comments throughout.

\section{References}

ADAME-ÁLVAREZ, R.-M., MENDIOLA-SOTO, J. \& HEIL, M. (2014). Order of arrival shifts endophytepathogen interactions in bean from resistance induction to disease facilitation. FEMS microbiology letters, 355(2): 100-107.

ARNOLD, A.E. (2003). Fungal endophytes limit pathogen damage in a tropical tree. Proceedings of the National Academy of Sciences, 100(26): 15649-15654.

BARHAM, E., SHARROCK, S., LANE, C. \& BAKER, R. (2015). An International Plant Sentinel Network. Sibbaldia, 13: 83-98.

BEBBER, D.P., HOLMES, T. \& GURR, S.J. (2014). The global spread of crop pests and pathogens. Global Ecology and Biogeography, 23(12): 1398-1407.

BRASIER, C. (2008). The biosecurity threat to the UK and global environment from international trade in plants. Plant Pathology, 57(5): 792-808.

BRASIER, C. \& WEBBER, J. (2010). Plant pathology: sudden larch death. Nature, 466(7308): 824-825.

BUSBY, P.E., PEAY, K.G. \& NEWCOMBE, G. (2015). Common foliar fungi of Populus trichocarpa modify Melampsora rust disease severity. New Phytologist, 209(4): 1681-1692.

BUSBY, P.E., RIDOUT, M. \& NEWCOMBE, G. (2016). Fungal endophytes: modifiers of plant disease. Plant Molecular Biology, 90(6): 645-655.

CHEAH, L.-H., MARSH, A.T., MCNEILL, M.R. \& HEDDERLEY, D.I. (2009). Evaluation of disinfectant products for microbial decontamination of imported used footwear. New Zealand Plant Protection, 62: 130-135.

CORLETT, R.T. (2016). Plant diversity in a changing world: Status, trends, and conservation needs. Plant Diversity, 38(1): 10-16.

DESPREZ-LOUSTAU, M., ROBIN, C., BUEE, M., COURTECUISSE, R., GARBAYE, J., SUFFERT, F., SACHE, I. \& RIZZO, D. (2007). The fungal dimension of biological invasions. Trends In Ecology \& Evolution, 22(9): 472-480.

DESPREZ-LOUSTAU, M.-L., AGUAYO, J., DUTECH, C., HAYDEN, K.J., HUSSON, C., JAKUSHKIN, B., MARÇAIS, B., PIOU, D., ROBIN, C. \& VACHER, C. (2015). An evolutionary ecology perspective to address forest pathology challenges of today and tomorrow. Annals of Forest Science, 73: 45-67.

DESPREZ-LOUSTAU, M.-L., COURTECUISSE, R., ROBIN, C., HUSSON, C., MOREAU, P.-A., BLANCARD, D., SELOSSE, M.-A., LUNG-ESCARMANT, B., PIOU, D. \& SACHE, I. (2009). Species diversity and drivers of spread of alien fungi (sensu lato) in Europe with a particular focus on France. Biological Invasions, 12(1): 157-172.

ELLIOT, M., MEAGHER, T.R., HARRIS, C., SEARLE, K., PURSE, B.V. \& SCHLENZIG, A. (2013). The epidemiology of Phytophthora ramorum and $P$. kernoviae at two historic gardens in Scotland. In: FRANKEL, S.J., KLIEJUNAS, J.T., PALMIERI, K.M. \& ALEXANDER, J.M. (tech. co-ords), Proceedings of the Sudden Oak Death Fifth Science Symposium, June 19-22, 2012, Petaluma, CA, USA. US Department of Agriculture, Forest Service, Pacific Southwest Research Station, Albany, CA, pp. 23-32.

ENNOS, R.A. (2015). Resilience of forests to pathogens: an evolutionary ecology perspective. Forestry, 88(1): 41-52.

ERWIN, D.C. \& RIBEIRO, O.K. (1996). Phytophthora Diseases Worldwide. APS Press, St. Paul, MN.

ESCHEN, R., BRITTON, K., BROCKERHOFF, E., BURGESS, T., DALLEY, V., EPANCHIN-NIELL, R.S., GUPTA, K., HARDY, G., HUANG, Y., KENIS, M., KIMANI, E., LI, H.-M. ET AL. (2015). International variation in phytosanitary legislation and regulations governing importation of plants for planting. Environmental Science \& Policy, 51: 228-237.

\section{EUROPEAN PARLIAMENT AND COUNCIL OF} THE EUROPEAN UNION (2016). Regulation (EU) 2016/2031 of the European Parliament of the Council of 26 October 2016 on protective measures against pests of plants, amending Regulations (EU) No 228/2013, (EU) No 652/2014 
and (EU) No 1143/2014 of the European Parliament and of the Council and repealing Council Directives 69/464/EEC, 74/647/EEC, 93/85/ EEC, 98/57/EC, 2000/29/EC, 2006/91/EC and 2007/33/EC. 2016/2031. Available online: https:// eur-lex.europa.eu/legal-content/EN/TXT/HTML/? uri=CELEX:32016R2031\&from=EN (accessed July 2019).

FISHER, M.C., HENK, D.A., BRIGGS, C.J., BROWNSTEIN, J.S., MADOFF, L.C., MCCRAW, S.L. \& GURR, S.J. (2012). Emerging fungal threats to animal, plant and ecosystem health. Nature, 484(7393): 186-194.

GILBERT, G. (2002). Evolutionary ecology of plant diseases in natural ecosystems. Annual Review of Phytopathology, 40: 13-43.

HARRIS, A.R. \& WEBBER, J.F. (2016). Sporulation potential, symptom expression and detection of Phytophthora ramorum on larch needles and other foliar hosts. Plant Pathology, 65(9): 1441-1451.

IPPC (1997). International Plant Protection Convention, p. 18. Available online: www. ippc.int/static/media/files/publication/ en/2019/02/1329129099_ippc_2011-12-01_ reformatted.pdf (accessed July 2019).

LEIFERT, C. \& CASSELLS, A.C. (2001). Microbial hazards in plant tissue and cell cultures. In Vitro Cellular \& Developmental Biology - Plant, 37(2): 133-138.

LIEBHOLD, A.M., BROCKERHOFF, E.G., GARRETT, L.J., PARKE, J.L. \& BRITTON, K.O. (2012). Live plant imports: the major pathway for forest insect and pathogen invasions of the US. Frontiers in Ecology and the Environment, 10(3): 135-143.

MARCHETTI, V., MANCIANTI, F., CARDINI, G. \& LUCHETTI, E. (2006). Evaluation of fungicidal efficacy of benzalkonium chloride (Steramina G u.v.) and Virkon-S against Microsporum canis for environmental disinfection. Veterinary Research Communications, 30(3): 255-261.

MCDONNELL, G. \& RUSSELL, A.D. (1999). Antiseptics and disinfectants: activity, action, and resistance. Clinical Microbiology Reviews, 12(1): 147-179.

MOUNCE, R., SMITH, P. \& BROCKINGTON, S. (2017). Ex situ conservation of plant diversity in the world's botanic gardens. Nature Plants, 3(10): 795-802.
PARKE, J.L. \& GRÜNWALD, N.J. (2012). A systems approach for management of pests and pathogens of nursery crops. Plant Disease, 96(9): 1236-1244.

PIMM, S.L. \& RAVEN, P.H. (2017). The fate of the world's plants. Trends in Ecology \& Evolution, 32(5): 317-320.

POWER, A.G. \& MITCHELL, C.E. (2004). Pathogen spillover in disease epidemics. The American Naturalist, 164(s5): S79-S89.

ROONEY-LATHAM, S., BLOMQUIST, C.L., KOSTA, K.L., GUO, Y.Y., WOODS, P.W. \& SORIANO, M.C. (2018). Phytophthora species are common on nursery stock grown for restoration and revegetation purposes in California. Plant Disease. doi.org/10.1094/PDIS-01-18-0167-RE.

ROY, B.A., ALEXANDER, H.M., DAVIDSON, J., CAMPBELL, F.T., BURDON, J.J., SNIEZKO, R. \& BRASIER, C. (2014). Increasing forest loss worldwide from invasive pests requires new trade regulations. Frontiers in Ecology and the Environment, 12(8): 457-465.

ROYAL BOTANIC GARDEN EDINBURGH (2018). Catalogue of the Living Collections. Available online: https://data.rbge.org.uk/search/livingcollection (accessed July 2019).

SANTINI, A., GHELARDINI, L., DE PACE, C., DESPREZ-LOUSTAU, M.L., CAPRETTI, P., CHANDELIER, A., CECH, T., CHIRA, D., DIAMANDIS, S., GAITNIEKIS, T., HANTULA, J., HOLDENRIEDER, O. ET AL. (2013).

Biogeographical patterns and determinants of invasion by forest pathogens in Europe. New Phytologist, 197(1): 238-250.

SIKES, B.A., BUFFORD, J.L., HULME, P.E., COOPER, J.A., JOHNSTON, P.R. \& DUNCAN, R.P. (2018). Import volumes and biosecurity interventions shape the arrival rate of fungal pathogens. PLOS Biology, 16(5): e2006025.

SIMBERLOFF, D. (2009). The role of propagule pressure in biological invasions. Annual Review of Ecology, Evolution, and Systematics, 40(1): 81-102.

SIMS, L., TJOSVOLD, S., CHAMBERS, D. \& GARBELOTTO, M. (2019). Control of Phytophthora species in plant stock for habitat restoration through best management practices. Plant Pathology, 68(1): 196-204.

STERGIOPOULOS, I. \& GORDON, T.R. (2014). 
Cryptic fungal infections: the hidden agenda of plant pathogens. Frontiers in Plant Science, 5. doi. org/10.3389/fpls.2014.00506.

SUSLOW, K. (2007). Recommended industry best management practices for the prevention of Phytophthora ramorum introduction in nursery operations. In: FRANKEL, S.J., KLIEJUNAS, J.T. \& PALMIERI, K.M. (tech. co-ords), Proceedings of the Sudden Oak Death Third Science Symposium, March 5, 2007, Santa Rosa, CA, USA. US Department of Agriculture, Forest Service, Pacific Southwest Research Station, Albany, CA, pp. 115-128. 